\title{
Education sector response to early and unintended pregnancy: A policy dialogue in Homa Bay County, Kenya
}

\author{
Chi-Chi Undie \\ Population Council \\ Ian MacKenzie \\ Harriet Birungi \\ Population Council \\ Stephen Barongo \\ Diosiana Ahindukha
}

See next page for additional authors

Follow this and additional works at: https://knowledgecommons.popcouncil.org/departments_sbsr-rh

Part of the Demography, Population, and Ecology Commons, Education Policy Commons, Family, Life Course, and Society Commons, Health Policy Commons, International Public Health Commons, and the Maternal and Child Health Commons

How does access to this work benefit you? Let us know!

\section{Recommended Citation}

Undie, Chi-Chi, lan MacKenzie, Harriet Birungi, Stephen Barongo, Diosiana Ahindukha, and Caleb Omondi. 2015. "Education sector response to early and unintended pregnancy: A policy dialogue in Homa Bay County, Kenya," STEP UP Meeting Report. Nairobi: Population Council. 


\section{Authors}

Chi-Chi Undie, Ian MacKenzie, Harriet Birungi, Stephen Barongo, Diosiana Ahindukha, and Caleb Omondi 


\section{STEP}

STRENGTHENING EVIDENCE FOR PROGRAMMING ON UNINTENDED

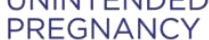

KENYA

MEETING

REPORT

DECEMBER 2015

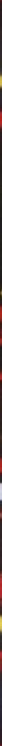

Education Sector Response to Early and

Unintended Pregnancy: A Policy Dialogue in

Homa Bay County, Kenya

CHI-CHI UNDIE, IAN MACKENZIE, HARRIET BIRUNGI

Population Council

STEPHEN BARONGO, DIOSIANAAHINDUKHA, CALEB OMONDI

Homa Bay County Department of Education, Ministry of Education
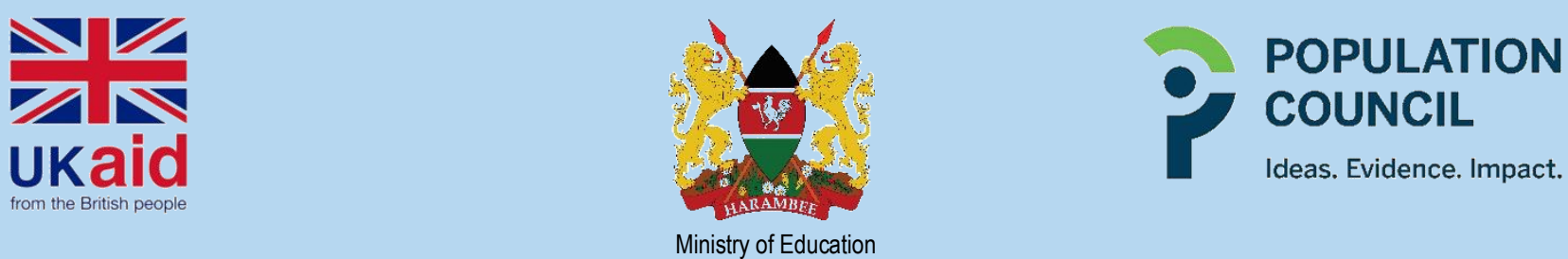
Education Sector Response to Early and Unintended Pregnancy: A Policy Dialogue in Homa Bay County, Kenya

CHI-CHI UNDIE, IAN MACKENZIE, HARRIET BIRUNGI Population Council

STEPHEN BARONGO, DIOSIANA AHINDUKHA, CALEB OMONDI Homa Bay County Department of Education, Ministry of Education

STEP UP MEETING REPORT

DECEMBER 2015
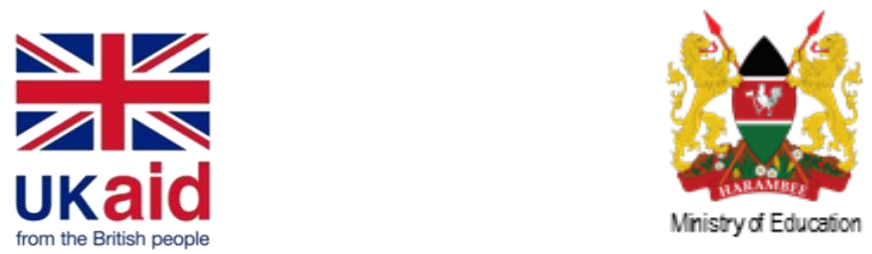
The STEP UP (Strengthening Evidence for Programming on Unintended Pregnancy) Research Programme Consortium (RPC) generates policy-relevant research to promote an evidence-based approach for improving access to family planning and safe abortion. STEP UP focuses its activities in five countries: Bangladesh, Ghana, India, Kenya, and Senegal. STEP UP is coordinated by the Population Council in partnership with the African Population and Health Research Center; The International Center for Diarrhoeal Disease Research -Bangladesh (icddr-b), the London School of Hygiene and Tropical Medicine; Marie Stopes International; and Partners in Population and Development. STEP UP is funded by UK aid from the UK Government. www.stepup.popcouncil.org

\section{POPULATION COUNCIL \\ Ideas. Evidence. Impact.}

The Population Council confronts critical health and development issues-from stopping the spread of HIV to improving reproductive health and ensuring that young people lead full and productive lives. Through biomedical, social science, and public health research in 50 countries, we work with our partners to deliver solutions that lead to more effective policies, programs, and technologies that improve lives around the world. Established in 1952 and headquartered in New York, the Council is a non-governmental, non-profit organization governed by an international board of trustees. www.popcouncil.org

Suggested citation: Undie C, Mackenzie I, Birungi H, Barongo S, Ahindukha D, and Omondi C. 2015. "Education sector response to early and unintended pregnancy: A policy dialogue in Homa Bay County, Kenya," STEP UP Meeting Report. Nairobi.

\section{(C) 2015 Population Council}

Please address any inquiries about STEP UP to the RPC co-directors:

Dr. Harriet Birungi, hbirungi@popcouncil.org

Dr. lan Askew, iaskew@popcouncil.org

Funded by

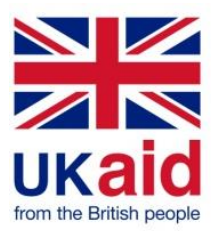




\section{Table of Contents}

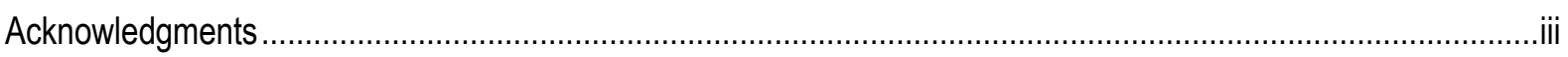

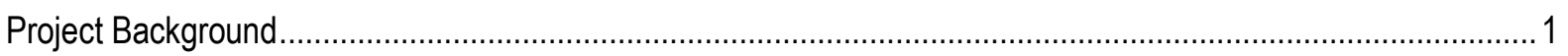

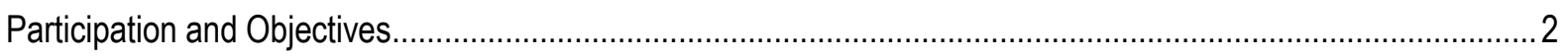

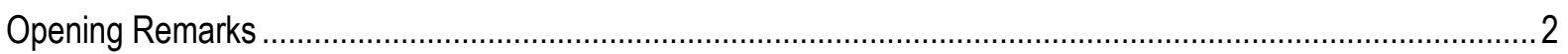

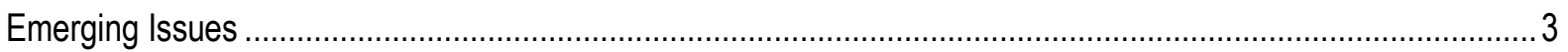

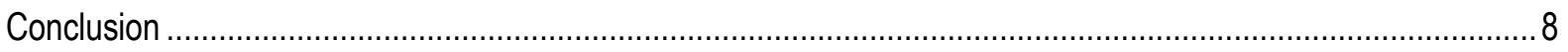

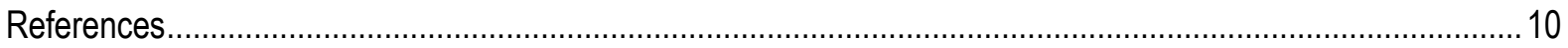

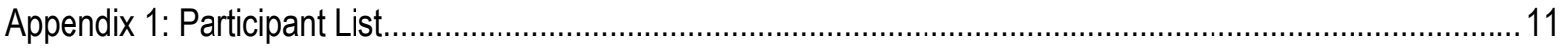

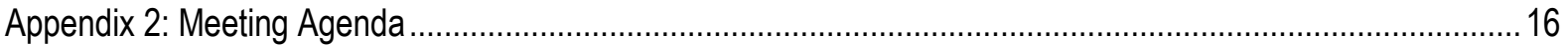




\section{Acknowledgments}

We gratefully acknowledge financial support from the Partnership to Strengthen Innovation and Practice in Secondary Education.

Our appreciation goes to the Homa County Department of Education, including the Sub-County Directors of Education in particular, who attended the policy dialogue event described in this report. We also would like to sincerely thank all the school principals who devoted their time to the policy dialogue. Our perspectives on the implementation of the school re-entry policy were greatly enriched by their discussions.

We owe a debt of gratitude to Jane Musia for her tireless efforts in coordinating the highly successful meeting. We express our sincere thanks to colleagues and interns at the Population Council for excellent technical and/or logistical support during the meeting: Joyce Ombeva, Janet Munyasya, Francis Obare, and Nicolas Camara.

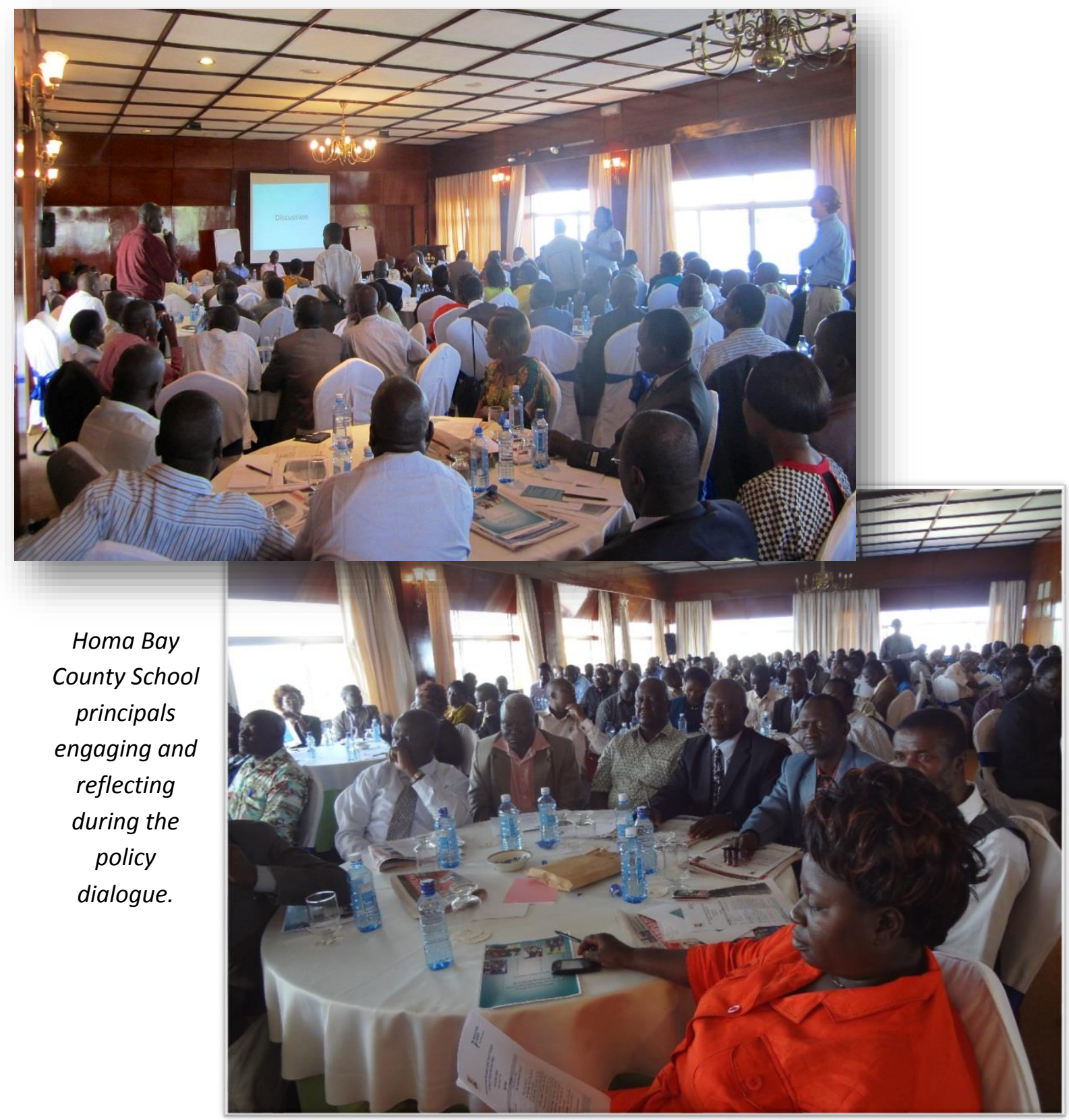




\section{Project Background}

In collaboration with the Strengthening Evidence for Programming on Unintended Pregnancy (STEP UP) Research Programme Consortium, the Population Council has implemented a project since 2014 to increase the demand for secondary school education in Homa Bay County, Kenya - an area characterized by high, unintended teenage pregnancy and female school drop-out rates. The main strategy employed for achieving this goal involves drawing on various communication channels for enhancing awareness in schools and communities of Kenya's school re-entry policy for outof-school teenage mothers. This policy was introduced in 1994 to facilitate pregnant learners' re-entry into the school system after childbirth. It is undergirded by the country's National School Health Policy, which permits pregnant learners to remain in school for as long as possible.

The communication channels employed under the project to increase awareness of the school re-entry policy include: dialogues with school principals; an interactive media campaign targeting schools and communities; and evidence-based advocacy ${ }^{1}$ for stakeholder adherence to the policy implementation guidelines. The overall strategy is expected to lead to the following changes in Homa Bay County:

- revitalization of Kenya's school re-entry policy among stakeholders (e.g., Ministry of Education officials, out-ofschool teenage mothers, schools, communities);

- improved implementation of Kenya's school re-entry policy; and

- enhanced demand for, and access to, secondary school education for out-of-school teenage mothers.

To foster awareness of the school re-entry policy in Homa Bay County schools, the Population Council collaborated with the Homa Bay County Department of Education (Ministry of Education) to convene a policy dialogue for all principals of public, day, girls-only, and co-educational secondary schools in Homa Bay County. The policy dialogue was held on August 1, 2014 in Kisumu, Kenya. This report details the proceedings of the meeting.

\section{Box 1: Guidelines for Implementing the School Re-entry Policy}

$\checkmark$ Girls who become pregnant should be admitted back to school unconditionally.

$\checkmark$ Head teachers, District, and Municipal Education Officers should assist such girls to join other schools to avoid psychological and emotional suffering.

$\checkmark$ Intensive guidance and counseling should be provided to affected girl, parents, teachers, and other girls in school.

$\checkmark$ Once a girl is sent home, the parents should be summoned to the school and receive some counseling, after which they should take their daughter home. Head teachers and other teachers should be understanding and patient while handling cases of this nature.

$\checkmark$ The school should keep in touch with such girls and their parents so as to monitor what is happening and provide the necessary moral, emotional, and spiritual support. Counseling for both the girl and the parents should not be discontinued.

$\checkmark$ The parents should seek readmission of their daughter to school after the baby is weaned. Head teachers should provide the necessary help in this regard. In case of any problem, the Provincial, District and Municipal Education Officers should assist.

$\checkmark$ Other girls in the school should be counseled on consequences of irresponsible behavior, adolescent sexuality, boy/girl relationships, negative peer influences, building self-confidence and self-esteem.

$\checkmark$ Those who make girls pregnant should be exposed. For example, teachers and other adults should face legal action. Boys should be given counseling so that they can take responsibility for their actions.

Source: MOE, 1998, pp.1-2 (as cited in Muganda-Onyando \& Omondi, 2008, p.45).

\footnotetext{
1 'Advocacy' is defined here as 'the continuous and adaptive process of gathering, organizing and formulating information and data into an effective argument, which is then communicated to policy-makers through various interpersonal and mass media communication channels. Through advocacy, [we seek] to influence policymakers, political and social leaders, to create an enabling policy and legislative environment and allocate resources equitably' (UNICEF, n.d., p. 12.).
} 


\section{Participation and Objectives}

Nearly two hundred participants attended the one-day meeting, representing the Homa Bay County Department of Education; the Population Council; the Centre for Social Sector, Education, and Policy Analysis; and 171 school principals (see Appendix 1 for a participant list).

The policy dialogue was guided by the following specific objectives:

- Provide a forum for school principals to be reminded of, and to deliberate upon, existing education policies developed to ensure continued schooling for pregnant/parenting learners;

- Gain a sense of the prevailing attitudes, beliefs, and perceptions about such policies among school principals;

- Gain insight into facilitators and barriers to implementing such policies from the perspective of school principals; and

- Identify good practices in the implementation of these policies by school principals.

The meeting provided an opportunity for experience-sharing, lesson-learning, and problem-solving among participants. For the Homa Bay County Department of Education, the policy dialogue was also a forum for taking stock of progress in regard to school re-entry policy implementation.

The meeting was structured around plenary sessions (which included presentations and discussion) and small group discussions (see Appendix 2 for the agenda).

\section{Opening Remarks}

The policy dialogue event was officially opened by Mr. Stephen Barongo, Homa Bay County Director of Education. Mr. Barongo cordially welcomed participants and thanked them for their contributions toward girls' education in the county. He reminded them that education is a basic right within the Constitution of Kenya, and highlighted early marriage as being one of several key issues plaguing Homa Bay. Mr. Barongo also pinpointed the issue of unsafe abortion in Homa Bay, urging school principals to counsel pregnant learners compassionately in order to avoid this circumstance. Emphasizing that the fifth Education for All goal has to do with eliminating gender disparities by 2015, Mr. Barongo affirmed the commitment of the Government of Kenya to achieving this goal. He enumerated several relevant policy responses that demonstrate this commitment, including:

$\checkmark$ Development of the Gender in Education policy;

$\checkmark$ Development of a gender-responsive curriculum as recommended in the Gender in Education policy;

$\checkmark$ Implementation of affirmative action, involving the incorporation of male teachers into early childhood development;

$\checkmark$ Provision of sanitary pads, school bags, uniforms, and shoes, to learners;

$\checkmark$ Establishment of low-cost boarding schools, particularly for girls;

$\checkmark$ Provision of separate toilets in schools for girls and boys;

$\checkmark$ Advocacy against retrogressive cultural practices (e.g., female genital cutting); and

$\checkmark$ Enforcement of the re-admission of girls who dropped out of school due to pregnancy. 
The Homa Bay County Director of Education urged participants to demonstrate their commitment to the county by supporting the implementation of the school re-entry policy. He concluded by saying, 'When you educate a man, you educate an individual. When you educate a woman, you educate the community.'

Following the opening remarks, a framing presentation was given by the Population Council to situate the issue of unintended pregnancy in schools in the context of Homa Bay County. The presentation drew on available statistics for Homa Bay around teenage pregnancy, compared to the national picture; outlined Kenya's policy responses to school pregnancy; and delineated the contents of the school re-entry policy and the National School Health Policy. Subsequently, interactive sessions commenced via the plenary and small group discussions. The latter were guided by the following question prompts:

- What are your opinions regarding the school re-entry policy?

- What are your opinions about permitting pregnant learners to remain in school for as long as possible, as stipulated in the National School Health Policy?

- To what extent have you been able to implement the re-entry policy in your school?

- What barriers/factors have prevented or hindered the implementation of this policy in your school?

- What factors have helped you to implement the re-entry policy for girls in your school?

- What are some of the best practices in implementing the school re-entry policy that you can share from personal experience?

Highlighted in the remainder of this report are the key themes and discussion points that emerged from the plenary and small group discussions.

\section{Emerging Issues}

Issues arising from the dialogue session enabled school principals to reflect on the history behind Kenya's school re-entry policy, their designated role in implementing the policy, and their challenges and successes in doing so. The presence of Ministry of Education representatives at the meeting also provided an opportunity for principals to specify their support needs in order to ensure optimal implementation of this policy in the future.

Critical issues emerging from the one-day policy dialogue are detailed below.

\section{- Unintended pregnancy among learners is a key concern of school principals.}

Repeat pregnancies by parenting girls re-entering school were continually highlighted by participants during the meeting as a major concern. School principals noted with consternation that many re-entering girls (who initially left school due to unintended pregnancy) ended up having multiple pregnancies. Some therefore regarded it as futile to promote school re-entry for teenage mothers. Furthermore, participants voiced concerns about pregnancyrelated illnesses and dietary needs of pregnant learners, and pointed out that they were ill-equipped to attend to such matters in their school contexts. Unsafe abortion by students was also a recurrent theme of these discussions. A number of principals viewed early and proactive detection of student pregnancy by schools as a means of mitigating unsafe and latestage abortions, which could adversely affect the health of students.

I have had fifteen pregnant girls in my school in one term.

--Participant comment 
As a result of these issues, some principals raised the need for accessible contraceptive services for students in general. On the other hand, a number of principals pointed out that some of their female students were married and therefore 'needed' family planning. However, the majority of school principals remained silent on the issue of contraception during this plenary discussion, and one only one principal publicly argued against making contraception accessible to students. A few participants opined that having special schools solely for pregnant learners would enhance the implementation of the school re-entry policy by helping to ensure that the specific needs of such learners can be attended to. Discussions around this topic clarified the need for further dialogue with principals on this issue, and for context-appropriate interventions for mitigating unintended pregnancy in schools.

\section{- Efforts must be made to reframe unintended pregnancy in schools as a 'rights' issue, as opposed to a 'disciplinary' issue.}

Plenary and group discussions demonstrated the tensions that participants experienced in viewing unintended pregnancy in schools beyond the traditional, disciplinary framework with which the phenomenon has historically been associated. Despite the school re-entry policy's clause on the unconditional readmission of parenting students, many school principals were of the opinion that parenting girls (who left school due to pregnancy) should only be readmitted if they demonstrated remorse for falling pregnant. Participants noted that parenting students were more likely to be readmitted by schools if they were known to be well-behaved, showed academic promise, or were particularly talented in some area.

Sending a pregnant girl away from school was also seen by some principals as a measure to help ensure that their peers 'learn a lesson' and refrain from becoming pregnant themselves. The concern that readmitting teenage mothers into schools would have a negative influence on other students was a prevalent one among participants. These concerns plausibly derive from the training of school personnel, which frames school-based, unintended pregnancy as a disciplinary issue, deserving or requiring disciplinary measures. However, in the era of education rights and inclusive education, such training must be adjusted to emphasize the right of even pregnant and parenting learners to education. Importantly, such training should target both the pre-service and in-service levels.

\section{- Reputational risks for schools and school principals are an under-investigated aspect of the school re- entry implementation process.}

There is a need to understand the reputational risks that implementing the school re-entry policy poses for school principals. Participants devoted a considerable amount of time to discussing this subject. Schools' reputations were perceived to suffer as a result of unintended pregnancy, partly because of principals' conceptualization of pregnancy as disability. School principals were of the opinion that pregnant learners (who are presumed to be perpetually ill) would affect their schools' 'Mean Grade' (an average score/ranking given to each school annually, based on the combined average grade of its students).

Until education is all-round (holistic), rather than focused on 'The Mean,' this [school re-entry] policy will never move anywhere.

--Participant comment

School principals felt pressurized to ensure that as many students as possible had strong grades so that their schools could maintain respectable 'Mean Grades.' A respectable score would draw the positive attention of prospective parents and students, and would ensure that the school concerned remained in demand. Balancing the Ministry of Education's expectation for schools to produce good grades with its expectation for schools to keep pregnant learners (who were perceived to perform poorly) in school was seen as a major challenge by many principals. 
Principals explained that, in addition to their schools' reputations, they also had their own professional reputations to protect. Some participants who had tried to encourage school continuity for pregnant learners suffered damage to their reputations, being accused by the community of promoting immorality in school. Maintaining their professional reputation before prospective parents when visibly pregnant learners are present in school was noted to pose a formidable challenge for principals. Others voiced concerns about the prevalent assumption

We've been asked [by parents] if our schools are maternity wards or pregnancy centers.

--Participant comment that principals are often perpetrators of sexual violence and responsible for the pregnancies experienced by their students. These concerns provided further incentive for school principals to ensure that pregnant learners did not feature in their school environment.

\section{- Engagement of key stakeholders in policy development is essential for avoiding policy misalignment and ensuring effective implementation.}

The lack of involvement of school principals in developing the school re-entry policy was highlighted by participants as a barrier which led to a lack of understanding of the policy, its rationale, and implementation procedures. Indeed, out of the 171 school principals in attendance, none had ever seen an actual copy of the school re-entry policy. As one participant explained: 'We have gone through hard life because of policies that we were not involved in. ... We were never inducted. We were

I think the principal is a lone-ranger in the fight against teenage pregnancy.

--Participant comment never told what to do.'

As the dialogue provided space for principals to consider the policy, questions arose during the meeting about the proper timing of readmission for parenting girls returning to school. While the school re-entry policy implementation guidelines indicate that readmission should be sought 'after the baby is weaned' (see Box 1), the National School Health Policy stipulates that ' $[n]$ ewborn babies must be allowed the benefit of breastfeeding as much as possible including exclusive breastfeeding for six months and introduction of complementary feeding at 6 months of age while continuing breastfeeding' (MOPHS \& MOE, 2009, p. 23). However, these instructions imply that all parenting girls will want to breastfeed, and for the same length of time - or that all pregnant learners will carry their pregnancies to term. Participants agreed that the timing of readmission should be decided on a case-by-case basis, and should depend on several factors, including the point at which the student left school, the duration of her time away from school, and her own perceived capacity to cope academically at a particular stage of readmission. Part of the discussion centered on the fact that, while the school re-entry implementation guidelines indicate that pregnant learners should be 'sent home,' the National School Health Policy states that such learners 'shall be allowed to continue with classes for as long as possible' (ibid.). This instance of policy misalignment left school principals uncertain of how to effectively implement the school re-entry policy. The discussion underscored the need to institutionalize the periodic sensitization of principals by the Ministry of Education, in addition to making actual policy documents available to new cohorts of stakeholders.

\section{- Parents are important stakeholders in the school re-entry process.}

A common refrain during the discussion sessions centered on the need to bring parents on board as part of the school re-entry process. School principals pointed out that while schools are often accused of having inadequate responses for mitigating unintended pregnancy, the roles and responsibilities of parents and homes are usually overlooked. Parents were noted to have several capacity-building needs, including: parenting classes

Let's start with the parents. ... A lot of the factors that lead to pregnancy should be addressed at home.

--Participant comment 
to provide support and know-how for raising teenage girls; knowledge of how to maintain strong relationships with school administrations (which was said to facilitate easier access to school re-entry support); and sensitization on the fact that a girl's pregnancy should not spell the end of her education.

The issue of childcare for teenage mothers was also raised in the context of this discussion. While there was agreement that some parents would be willing to help out with childcare, meeting participants pointed out that a considerable proportion of pregnant and parenting learners in Homa Bay happen to be orphans. Finding ways for secondary schools to forge links with the Early Childhood Development and Education arm of the Homa Bay County Department of Education was a recommended action for attending to this issue.

\section{- While it is an important issue, stigma is not always a factor in girls' re-entry decisions.}

There was a perception among some participants that parenting girls prefer to be readmitted to other schools (rather than to the ones in which they fell pregnant) to avoid stigma and discrimination. Some principals spoke from personal experience with pregnant learners in their schools, who opted for readmission elsewhere. Meeting participants also pointed out that pregnant girls' self-stigma was often responsible for their leaving school, as opposed to coercion by school principals. Nonetheless, a number of principals also had personal experiences with girls who preferred to return to their original schools after pregnancy, and actually did so.

The school re-entry policy implementation guidelines presume that parenting students would want to re-enter different schools 'to avoid psychological and emotional suffering' (see Box 1), and offer instructions for supporting such students to find new schools as a result. Although well-intentioned, it is imperative to also encourage and support students who are still comfortable in their original school environment to re-enter these settings. Such efforts should be coupled with concrete efforts to address school-based stigma and discrimination against pregnant/parenting learners.

\section{- Cultural realities in Homa Bay can serve to strengthen responses for parenting students.}

Participants drew attention to certain cultural issues in Homa Bay County which need to be considered and understood to ensure optimal responses for parenting girls wishing to re-enter school. For instance, participants noted that childbirth is celebrated in the community. The experience of childbirth raises a teenage girl's status and that of the newborn's father in the eyes of the community. While this cultural reality may pose challenges for girls' education, school principals noted that it could also be helpful in ensuring that school re-entry by parenting girls is not hindered by a sense of 'shame' (due to early pregnancy) on the part of parents. Participants also indicated that parents who take pride in their daughters' pregnancies would be more likely to provide childcare support.

The school re-entry policy guidelines include a counseling stipulation for boys 'so that they can take responsibility for their actions' (see Box 1). Furthermore, the National School Health Policy indicates that '[c]hild-fathers (boys less than 18 years) shall receive counseling and rehabilitation' (MOPHS \& MOE, 2009, p. 23). School principals questioned the utility of these counseling and rehabilitation requirements, given that such boys are regarded as 'heroes' in their communities due to their fatherhood status. It was agreed that the targets and content of such counseling would have to be carefully determined in order to ensure it is beneficial for all concerned. Several participants voiced the opinion that there should be penalties for boys and men responsible for school girls' pregnancies. However, the goal of keeping both girls and boys in school, despite their complicity in school-based unintended pregnancy, was emphasized. 
Principals also raised the cultural taboo of parents sharing a dwelling unit with daughters of reproductive age. As a consequence of this taboo in Homa Bay County, adolescent girls often share dwelling units with their much more lenient grandmothers. Consequently, parents are less able to monitor activities that could lead to unintended pregnancy. Looking forward, this reality would be important to consider in pregnancy prevention programs.

\section{- Despite minimal resources, principals are innovating with good practices to respond to unintended pregnancy in schools.}

Although none of the school principals in attendance had ever seen a copy of the school re-entry policy, and a considerable proportion $(20 \%)$ had not heard of it, many principals were responding to girls' school re-entry needs in useful and inspiring ways. Small group and plenary sessions were devoted to giving participants an opportunity to share their individual practices with one another, and to ask/answer questions about modalities for implementing them. A summary of good practices being implemented by principals in their individual schools is provided here:

$\checkmark$ Using parenting students as resources: e.g., having such students talk to other girls in school about the realities of being pregnant or a teenage mother, as a means of steering them away from teenage pregnancy.

$\checkmark$ Introducing flexi-time for parenting students: e.g., giving such students longer break periods in order for them to return home to nurse their babies.

$\checkmark$ Setting up a 'nursing zone' for parenting students, rather than having them return home to nurse, thereby taking away from learning time.

$\checkmark$ Making arrangements with selected teachers for extra tutoring for parenting students, who often miss parts of classes when they return home to nurse.

$\checkmark$ Granting special permission to married, parenting students to leave school for a few hours in order to attend a family planning clinic.

$\checkmark$ Inquiring about pregnant learners' expected due dates, and advising them to leave school two months prior to prepare for delivery.

$\checkmark$ Maintaining contact with pregnant learners' parents after they have left school, to ensure that school reentry occurs.

$\checkmark$ Providing proper guidance and counseling.

These positive, independently-implemented practices demonstrate a great extent of willingness on the part of school principals to play a key role in implementing the school re-entry policy. Such efforts can and should be encouraged, supported, and built upon to ensure optimal implementation of the policy.

\section{- Additional stakeholders must be involved to holistically address unintended pregnancy and foster school re-entry at the secondary school level.}

Sub-County Directors of Education expressed concern over the fact that boarding school principals were not included in the policy dialogue. They noted that boarding schools are equally affected by unintended pregnancy, and that principals of such schools are actually more likely to prohibit the re-admission of parenting girls. They also highlighted the need to involve primary schools in school re-entry responses, given that school drop-out due to unintended pregnancy occurs at this level of schooling as well. While the importance of boarding schools in school re-entry processes is not debated, participants were informed that the current project focuses on secondary schools which benefit from Free Secondary Education (i.e., public day schools), to help minimize financial barriers for girls wanting to re-enter school. 
An additional concern emphasized by Sub-County Directors of Education had to do with motorcycle transporters (boda-bodas). The latter were strongly perceived by Directors and school principals alike as being responsible for a considerable proportion of unintended pregnancies among school-going girls, given their ubiquitous presence in the community as transportation providers between the home and school. However, recent findings from the baseline survey conducted to assess interventions under the current project are not clear on the complicity of bodabodas in school pregnancy (Undie, Birungi, Odwe, \& Obare, 2015). The vast majority of out-of-school teenage mothers (89\%) reported being impregnated by their 'boyfriends' - 37 percent of whom happened to be their fellow students when they were in school. The remaining $52 \%$ were reported to be boyfriends who were not fellow students (ibid.). It is unclear whether any boda-bodas fell in this category of non-student boyfriends, and were therefore not referred to by respondents as motorcycle transporters. Only 6 percent of out-of-school teenage girls specifically reported that 'boda-bodas' were responsible for the pregnancy that led to their school dropout.

Sub-County Directors of Education asked that future interventions to promote school re-entry for girls include Information, Education, and Communication materials based on the school re-entry policy and associated reproductive health issues. Importantly, school principals commented on the influence of Sub-County Directors of Education, noting that if the latter decided to prioritize the implementation and monitoring of the school re-entry policy, this would automatically become a priority for principals.

\section{Conclusion}

The policy dialogue event helped to create visibility around the issue of unintended pregnancy in schools and the need for a clear, strong education sector response to it. The event also fostered a sense of dignity and ownership among attendees, some of whom previously felt overlooked and unsupported by earlier processes of introducing the school re-entry policy. Additionally, the meeting deliberations underscored the need to update current policies based on issues emerging from the dialogue. To avoid policy misalignment, it would be essential for all related policies to be reviewed simultaneously.

Lessons learned from the policy dialogue will be incorporated into future interventions under the project, including an interactive media campaign that will target schools and communities, and advocacy activities with stakeholders to promote adherence to the school re-entry policy implementation guidelines.

Participants came to the end of the meeting inspired to redouble efforts collectively in Homa Bay County and in their individual schools based on lessons learned at the meeting. Feedback from school principals regarding the policy dialogue was overwhelmingly positive, and included written statements such as the following:

Thank you very much for the workshop; it was an eye-opener. Quite a number of us were not aware of the policy. Now, I want to believe that our girls will be handled properly in our schools when they seek re-entry after delivery.

Thank you abundantly for the wonderfully-conducted dialogue in Kisumu ... It is only with this degree of commitment that our girl child and indeed all children will have a more assured brighter future. The exposure has opened up my eyes at both a personal and administrative level and things will never be the same again for all kinds of vulnerabilities in the school set-up.

I wish to thank you sincerely for your encouragement for the girls who had dropped out of school to be given chance at school. Sincerely, I know the workshop was most useful to us principals 
of secondary schools of Homa Bay. Thanks so much, for I know if the program is intensified, it will save many girls from our community.

This was good. Keep it up.

It was so well-organized ... We are looking forward to a follow-up session.

The policy dialogue was brought to an official close by the Homa Bay County Teachers Service Commission Director, Mrs. Diosiana Ahindukha. She implored the school principals in attendance not to overlook the issue of unintended pregnancy in schools and the need for girls' school re-entry. In her words: 'Let us not bury our heads in the sand as principals.' She urged meeting participants to begin to use learnings from the policy dialogue to effect change in their individual schools, and within the Homa Bay County education system as a whole. Mrs. Ahindukha also asked that the Population Council take the concerns of the meeting participants seriously and use the evidence emanating from the project to provide guidance for ensuring the reincorporation of out-of-school teenage mothers into the education system. She concluded her speech with the following words: 'Thank you, Population Council, for the inclusive approach you have used in engaging us.' 


\section{References}

Ministry of Public Health and Sanitation, and Ministry of Education (2009). National School Health Policy. Nairobi: Government of Kenya.

Muganda-Onyando, R and Omondi M. (2008). Down the Drain: Counting the Costs of Teenage Pregnancy and School Dropout in Kenya. Nairobi: Centre for the Study of Adolescence.

Undie, C., Birungi, H., Odwe, G. and Obare, F. (2015). Expanding access to secondary school education for teenage mothers in Kenya: A baseline study report. STEP UP Technical Report. Nairobi

UNICEF (n.d.). Evidence-Based Advocacy for Gender in Education: A Learning Guide. Available at: http://www.unicef.org/eapro/advocacy_guide_FINAL4.pdf. [Accessed on February 12, 2015]. 


\section{Appendix 1: Participant List}

1. Margaret Kwame

2. Diosiana Ahindukha

3. Moses O. Amoth

4. Stephen O. Barongo

5. Justus M. Ichwara

6. Bernhards C. Kogolla

7. William O. Minyiu

8. Calleb Omondi

9. Oriyo E. Otieno

10. Were R. Sospeter

11. Nicolas Camara

12. Ian Mackenzie

13. Janet Munyasya

14. Jane Musia

15. Francis Obare

16. Joyce Ombeva

17. Chi-Chi Undie

\section{Homa Bay Sub-County}

18. Rose N. Onditi

19. Charles Ombogo

20. Margaret Otieno

21. Andrew Aduda

22. Nehemiah Ougo

23. Ezekiel Okumu

24. Ajigo Tom

25. Beldine Ochieng

26. Maurice Ajulu

27. W. Elisha

28. George Oyier

29. Ogaga J. Owuor

30. Peter Oloo N.

31. Odhiambo Lucy Anyango

32. Joyce Okwaro

33. Charles Owino Ober

34. Charles O. Ogonda

35. Gordon Matengo

36. Samuel Odhiambo Okelo

37. John O. Ogeice

38. Tobias Otieno A.

39. Tom Mimba

40. Peter O. Goga

41. Hellen A. Odhiambo

42. Osoro Johnstone

43. Nelson O. Yogo
Centre for Social Sector, Education, and Policy Analysis Homa Bay County Department of Education Homa Bay County Department of Education Homa Bay County Department of Education Homa Bay County Department of Education Homa Bay County Department of Education Homa Bay County Department of Education Homa Bay County Department of Education Homa Bay County Department of Education Homa Bay County Department of Education Population Council (Intern) Population Council (Intern)

Population Council

Population Council (Consultant)

Population Council

Population Council

Population Council

Bondo Mixed Secondary School

Chiga Mixed Secondary School

Dr. Mbai Majiwa Secondary School

God Kado Secondary School

God Marera Mixed Secondary School

Gogo Katuma Secondary School

Gul Kagembe Secondary School

Kuja Secondary School

Lala Mixed Secondary School

Ludhe Dongo Mixed Secondary School

Lwaho Mixed Secondary School

Maguti Mixed Secondary School

Marienga Secondary School

Marindi Girls Secondary School

Nyakwadha Secondary School

Nyalkinyi Mixed Secondary School

Nyandema Mixed Secondary School

Nyandiwa Mixed Secondary School

Nyanjanja Mixed Secondary School

Odienya Mixed Secondary School

Ogande Mixed Secondary School

Oluso Mixed Secondary School

Omoche Mixed Secondary School

Ongeti Mixed Secondary School

Onyege Secondary School

Opinde Mixed Secondary School 
44. Pinto E. Arum

45. Lawrence Oyamo

46. Millicent Onyango

47. Atieno Mary Ouko

48. Lucas A. Ogich

49. Meshack Odieny Aseno

50. Thomas Otieno

51. Kennedy Nyando

52. Martin Awi

53. Richard O. Odhiambo

54. Silas Agira

55. Obere Yunita

56. Daniel O. Obongo

57. James H.O. Billa

58. Ogwayo John Otieno

\section{Mbita Sub-County}

59. Opere Martin

60. Ogweno P.C. Okoma

61. Onyango Sana $Z$.

62. Bernard Anyango Ochieng'

63. Peter O. Ochieng

64. Tom O. Ochola

65. Collins D. Okeyo

66. Stephen Ngesa Ogwel

67. Walter O. Otie

68. Arthur A. Nyawara

69. Peter J.O. Ouma

70. Mourice Ochieng

71. Herine Abijah

72. Agnes Juma

73. Ongong'a Pius Owuor

74. Meshack Awino Nyakado

75. Clement Ogweno Midam

76. George O. Sewe

\section{Ndhiwa Sub-County}

77. Andrew Mbogo Wigwa

78. Otuka Charles

79. Benter A. Akendo

80. Pamela Achieng Ageyo

81. Hellen Awuor Opiyo

82. Ochieng Onyango

83. Daniel Waga Osanya

84. Paul Nyawade Opiyo

85. Janet Akoth Otieno
Otaro Mixed Secondary School

Pala Masogo Secondary School

Rangwe Girls Secondary School

Ruga Mixed Secondary School

St. Albert Chiepe Mixed Secondary School

St. Andrew's Got Rabuor Secondary School

St. Elizabeth Koyo Secondary School

St. Francis Anding' O M Secondary School

St. John Kabok Secondary School

St. Matthew's God Bondo Secondary School

St. Paul's Aoch Muga Secondary School

Sero Mixed Secondary School

Wiga Mixed Secondary School

Wi' Koteng Secondary School

Wiobiero Mixed Secondary School

Father Tillen Secondary School

Kamasengre Secondary School

Kamato Mixed D. Secondary School

Kayanja Mixed Secondary School

Mauta Secondary School

Ndhuru Secondary School

Ngodhe Secondary School

Nyakwei Secondary School

Nyandenga Secondary School

Otieno Kajwang Nyamaji Secondary School

Prof. Karega Mutahi

Rapora Secondary School

Rusinga Girls Secondary School

St. Stephen Kirindo Secondary School

St. William's Osodo Secondary School

USAO Secondary School

Wakula Secondary School

Waware Secondary School

Abura Mixed Secondary School

Andiwo Mixed Secondary School

Apoche Mixed Secondary School

Bishop Ochiel Nyagidha Girls Secondary School

Bongu Girls Secondary School

Gina Mixed Secondary School

Got Rahar Ojode Ndere Secondary School

Joshua Ojode Ndere Secondary School

Katanga Girls Secondary School 
86. Kabaka E. David

87. Tom Okatch

88. Thomas O. Oyamo

89. Dickson Keta

90. John Omolo Ouko

91. John Odongo

92. Auma Vincent Ouma

93. Martin Owino

94. Victor N. Kibwana

95. Otwande Andrea

96. Jaoko J. Phillip

97. Monica A. Omolo

98. Joseph O. Odhiambo

99. Marystella Ogol

\section{Rachuonyo North Sub-County}

100.Joram Osarehongo

101.Abel Odira Ogola

102. Vincent Andare Okumu

103.Tom O. Omolo

104.Tobias Omolo

105.Makokha Zackary

106. Charles O. Guna

107. Isaac O. Ouko

108. Naftal J. Obiero

109. Mathews Lunalo

110.John Okwanyo

111. Reuben O. Kodiango

112.Samuel Wasilwa

113.Jack Odongo

114. Malala Martin O.

115. Nyachira Odhiambo

116. Ouma O. Richard

117.Dennis Ochieng

118.Daniel Gaya

119. Omolo Nyakong

120.Belia M. Onjala

121.Edith A. Ong'ore

122.George O. Omondi

123. Ambonya Job

124.Aloice O. Obonyo

125. Oningu Moses 0 .

126. Joshua A. Amadi

127. Ben Odiango

128. Philomena A. Osolo
Koduogo Mixed Secondary School

Kome Secondary School

Langi Mixed Secondary School

Mbani Secondary School

Ojode Pala Mixed Secondary School

Ojode Unga Mixed Secondary School

Ongako Mixed Secondary School

Osure Mixed Secondary School

Otange Mixed Secondary School

Rapedhi Mixed Secondary School

Sagama Secondary School

St. Lucy's Odhiambo Rambo Secondary School

St. Peter's Rambusi Secondary School

Wanyara Mixed Secondary School

Akwakra Secondary School

George Agola Owuor Secondary School

Kamolo Mixed Secondary School

Kamwala Mixed Secondary School

Kanam Mixed Secondary School

Karabondi Bidii Secondary School

Kendu Muslim Secondary School

Kobila Secondary School

Kodhoch Mixed Secondary School

Koredo Mixed Secondary School

Kotonje Mixed Secondary School

Kowuour Secondary School

Lieta Mixed Secondary School

Miyuga Mixed Secondary School

Ngeta Mixed Secondary School

Nyakech Mixed Secondary School

Ojijo Oteko Mixed Secondary School

Omboga Mixed Secondary School

Osondo Mixed Secondary School

St. Innocent Jonyo Secondary School

St. John Seka Secondary School

St. Joseph Kobuya Mixed Secondary School

St. Joseph Miranga Secondary School

St. Martins Oluti

St. Mary's Nyakango Secondary School

Samanga Lutheran Secondary School

Siburi Mixed Secondary School

Wagwe Secondary School

Wikondiek Secondary School 


\section{Suba Sub-County}

129.Peter Wandera Wao

130. Jacob Otieno Dibogo

131.Dominic Sure

132. Aggrey O. Mbori

133.Samwell Gogo

134. Margaret A. Jamba

135. Fanny F. Odera

136. Shelemiah O. Wagaluka

137. Alphonce Odero

138.Francis Okinyi Ombaka

\section{Rachuonyo South Sub-County}

139. Vitalis A.

140.George Riwa

141. Hezbon Ombuyanyakongo

142. Rose A. Omolo

143. Aninda D. Otieno

144.Jared Ogwemo

145. Kungu A. Mereza

146.Arthur Oketch

147. Oguk G. Manasseh

148. Ojuok Justus Okoth

149. Ominde M. Michael

150.Apaka Leonard Okoth

151. Odoyo Tubman G.B.

152. Merab A. Obonyo

153. Eunice Opiyo

154.Okeyo Okuta

155. Ogutu Christopher

156. Pamela A. R.

157. Joash Ojwang' Awuor

158. Mabel Aludira

159. George M. Abongu

160. Charles O. Alila

161.George O. Boro

162.Samuel Oluoch Owuor

163.Martin E. Odundo

164.Daniel Owaka

165. Okelo Samwel

166. Ochiewo Kenyatta

167. Eunice A Otieno

168. Ouma Godfrey

169. Richard Opiyo

170. Oyoo Tabu

171.Daniel Ouma Odoyo

172. Ogola Jorim
Kiabuya Mixed Secondary School

Kiembe Mixed Day Secondary School

Kisaku Secondary School

Kisegi Mixed Secondary School

Nyakiya Secondary School

Nyenga Mixed Secondary School

Magunga Township Secondary School

Mark Matunga Kiwa Secondary School

Obanga Secondary School

St. Marcelline Kigoto Secondary School

Adega Mixed Secondary School

Agoro Sare Mixed Secondary School

Apondo Mixed Secondary School

Atela Mixed Secondary School

Atemo Mixed Secondary School

Buoye Mixed Secondary School

Danish Obara Mixed Secondary School

Dol Mixed Secondary School

Gangre Mixed Secondary School

Got Agulu Mixed Secondary School

Harambee Mixed Secondary School

Kachieng Secondary School

Kadie Mixed Secondary School

Kakelo Mixed Secondary School

Kalanding' Mixed Secondary School

Kilusi Mixed Secondary School

Kolweny Mixed Secondary School

Kosele Mixed Secondary School

Kotienditi Mixed Secondary School

Kowidi Mixed Secondary School

Lwanda Mixed Secondary School

Mithiu Mixed Secondary School

Nyabola Mixed Secondary School

Nyafare Mixed Secondary School

Nyakiya Mixed Secondary School

Nyalenda Mixed Secondary School

Nyambare Mixed Secondary School

Nyamwaga Mixed Secondary School

Nyandiwa Mixed Secondary School

Nyasore Mixed Secondary School

Nyatindo Mixed Secondary School

Nywango Secondary School

Obisa Mixed Secondary School

Ogilo Mixed Secondary School 
173.Michael Akumu

174.Orinda John

175. William Kapere

176. Rose O. Edna

177.Paul Amolo

178. Elly Otieno

179. Roche S. Onyalo

180.Medrine K. Libaiga

181. Hezron A. Ayal

182.Joel Odongo Olielo

183.Desmond O. Odongo

184. Tobias Gor Okeyo

185.Mark Olonde

186. Ouma Frederick

187. David Onoka

188. Moses O. Ayieko

189. Belliah O. Odero
Ombek Mixed Secondary School Ongoro Mixed Secondary School Orera Mixed Secondary School Orinde Mixed Secondary School Otel Mixed Secondary School Otondo Mixed Secondary School Owiro Mixed Secondary School Pala Mixed Secondary School Ponge Lutheran Secondary School St. Linus Umai Mixed Secondary School St. Paul's Oriang Secondary School St. Peter's God Agak Secondary School St. Phillip's Nyabondo Secondary School St. Teresa's Nyalgosi Secondary School St. Thomas Omiro Secondary School Siany Mixed Secondary School Yala Kotieno Secondary School 


\section{Appendix 2: Meeting Agenda}

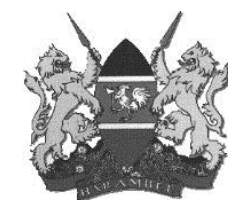

Ministry of Education

\section{POPULATION} COUNCIL

Ideas. Evidence. Impact.

Homa Bay County Secondary School Heads Dialogue on Kenya's School Re-entry Policy Imperial Hotel, Kisumu

Friday, August 1, 2014

\begin{tabular}{|c|c|c|}
\hline Time & Activity & Facilitator \\
\hline 8:00 & Registration & Population Council \\
\hline 9:00 & Opening Prayer and Introductions & Mr. Caleb Omondi - CQASO \\
\hline $9: 30$ & Brief Survey & Population Council \\
\hline 10:00 & Opening Remarks & Mr. Barongo - Homa Bay County Director of Education \\
\hline 10:15 & Introduction to Program & Chi-Chi Undie - Population Council \\
\hline 10: 45 & \multicolumn{2}{|l|}{ TEA BREAK } \\
\hline $11: 15$ & School Re-entry Policy & Chi-Chi Undie - Population Council \\
\hline 12:00 & Best Practices \& Barriers & Francis Obare - Population Council \\
\hline $1: 00$ & \multicolumn{2}{|l|}{ LUNCH } \\
\hline $2: 00$ & Best Practices \& Barriers Cont'd & Francis Obare - Population Council \\
\hline 3:00 & Next Steps and Way Forward & Chi-Chi Undie - Population Council \\
\hline $3: 30$ & Final Thoughts & Mr. Barongo - Homa Bay County Director of Education \\
\hline 4:00 & Closing remarks & $\begin{array}{l}\text { Mrs. Ahindukha - TSC Director of Education, Homa } \\
\text { Bay County } \\
\text { County Minister of Education, Homa Bay }\end{array}$ \\
\hline $4: 30$ & \multicolumn{2}{|l|}{$\begin{array}{l}\text { TEA BREAK } \\
\text { Administrative Issues \& Departure }\end{array}$} \\
\hline
\end{tabular}

